\title{
Activated carbons prepared from hazelnut shells, walnut shells and peanut shells for high $\mathrm{CO}_{2}$ adsorption
}

\author{
Katarzyna Lewicka \\ West Pomeranian University of Technology, Szczecin, Faculty of Chemical Technology and Engineering, Institute of \\ Inorganic Chemical Technology and Environment Engineering, Pulaskiego 10, 70-322 Szczecin, Poland \\ Corresponding author: e-mail: katarzyna.lewicka@zut.edu.pl
}

\begin{abstract}
Research treats about producing activated carbons for $\mathrm{CO}_{2}$ capture from hazelnut shells $(\mathrm{HN})$, walnut shells (WN) and peanut shells (PN). Saturated solution of $\mathrm{KOH}$ was used as an activating agent in ratio 1:1. Samples were carbonized in the furnace in the range of temperatures $600^{\circ} \mathrm{C}-900^{\circ} \mathrm{C}$. Properties of carbons were tested by $\mathrm{N}_{2}$ adsorption method, using BET equation, DFT method and volumetric $\mathrm{CO}_{2}$ adsorption method. With the increase of carbonization temperature specific surface area of studied samples increased. The largest surface area was calculated for samples carbonized at $900^{\circ} \mathrm{C}$ and the highest values of $\mathrm{CO}_{2}$ adsorption had samples: PN900 at $0^{\circ} \mathrm{C}$ $(5.5 \mathrm{mmol} / \mathrm{g})$ and $\mathrm{WN} 900$ at $25^{\circ} \mathrm{C}(4.34 \mathrm{mmol} / \mathrm{g})$. All of the samples had a well-developed microporous structure.
\end{abstract}

Keywords: activated carbon, biomass, nutshells, $\mathrm{CO}_{2}$ adsorption.

\section{INTRODUCTION}

$\mathrm{CO}_{2}$ as well as $\mathrm{CH}_{4}$ are considered as one of the greenhouse gases that contribute to anthropogenic global warming. Global warming has a destructive effect on climate, it can change ecosystems, increase contagious diseases and enlarge ozone hole. $\mathrm{CO}_{2}$ is exchanged among land surface, atmosphere and ocean. However, its excess disturbs natural balance and have a negative influence on Earth's climate. Combustion of fossil fuels and industrial gas emission are a major source of atmosphere pollution. Climate change is a quickly growing issue and governments start to look for new methods of preventing it. Natural reduction of pollution would take ages and is not possible because of the scale of the problem. These are the reasons why developing new techniques of capturing $\mathrm{CO}_{2}{ }^{1-7}$ are the main interest of many existing studies but the methods of $\mathrm{CO}_{2}$ conversion are developed as well ${ }^{8-12}$. Methane conversion to methanol ${ }^{13-15}$, formaldehyde ${ }^{13,16,17}$, methyl bisulfate ${ }^{18-23}$, carbon nanomaterials ${ }^{24-29}$, hydrogen ${ }^{30-35}$ is investigated very deeply but methane can be used as an alternative fuel vehicle ${ }^{36-38}$.

Most of the commercial activated carbons show too low $\mathrm{CO}_{2}$ adsorption capacity, therefore finding and developing new type of porous carbons was necessary ${ }^{39-44}$. Activated carbons can be prepared from the wide range of organic materials, such as agricultural wastes. Raw agricultural by-products can be used as a promising material for carbons production due to their many qualities ${ }^{45}$. They are extensively studied because of their good chemical stability, low ash content, porous structure, great adsorption capacity and low cost $\mathrm{t}^{35,39,45,46}$. Carbon adsorbents are broadly exploited for water ${ }^{47}$ and gas purification ${ }^{48,49}$, removal of metal ions ${ }^{50,51}$ and dyes ${ }^{52,53}$ and production of high purity substances ${ }^{45,54}$ but they can find many applications e.g. as catalysts ${ }^{5-57}$.

Biomass derived activated carbons are cheap and usually solve problem of wastes utilization. For example corncobs $^{4}$, rice husks ${ }^{58}$, almond shells ${ }^{58}$, coconut shells ${ }^{59}$, fruit stones ${ }^{60}$, molasses ${ }^{36,61,62}$, pomegranate peels ${ }^{63}$, tinder fungus ${ }^{63}$, mistletoe branches and leaves ${ }^{63}$, carrot peels ${ }^{63}$, kiwi fruit peels ${ }^{63}$, fern leaves ${ }^{63}$, sugar beet pulp ${ }^{63}$, sun flo- wer shells ${ }^{64}$, demineralized kraft lignin ${ }^{65}$, ebony wood ${ }^{66},{ }^{67}$, mahogany wood ${ }^{66}$, and nutshells ${ }^{67-70}$ were described as carbon precursors. Porous carbons can be prepared and activated in many different ways. The ability of activated carbons to capture $\mathrm{CO}_{2}$ depends on several factors that include activation method and type of starting material. These elements have a direct influence on the properties of the carbon, such as its porosity and surface area ${ }^{60}$.

There are not many studies describing the preparation of activated carbons from nutshells for $\mathrm{CO}_{2}$ capture. Most of the studies are focused on removing metal ions and dyes from aqueous solutions. Moreover, methods of preparation activated carbons are more complex than the one presented in this study. In other studies, physical activation or other activating agents were used ${ }^{64,71-74}$. There are no studies considering the preparation of activated carbons from hazelnut shells for $\mathrm{CO}_{2}$ adsorption. Furthermore, none of the publications compare three types of nutshells presented in this study.

The aim of this study was to evaluate $\mathrm{CO}_{2}$ adsorption capacity of activated carbons prepared from hazelnut shells, walnut shells and peanut shells at different carbonization temperatures, as well as to assess the size of the specific surface area and pore volume.

\section{EXPERIMENTAL}

Hazelnut shells (HN), walnut shells (WN) and peanut shells $(\mathrm{PN})$ were crushed to the particle size $0.3-1.6 \mathrm{~mm}$. Obtained material was mixed with saturated solution of potassium hydroxide in ratio 1:1 and left in the room temperature for $3 \mathrm{~h}$. Afterwards, impregnated samples were dried at $200^{\circ} \mathrm{C}$ for $19 \mathrm{~h}$. In the next step, material was grounded and put into quartz boats. Than pyrolyzed in a furnace at required temperature $\left(600^{\circ} \mathrm{C}, 700^{\circ} \mathrm{C}\right.$, $800^{\circ} \mathrm{C}$, and $900^{\circ} \mathrm{C}$ ) which was maintained for $1 \mathrm{~h}$ in constant nitrogen flow $18 \mathrm{dm}^{3} / \mathrm{min}$. After pyrolysis samples were grounded again. Obtained powder was washed with distilled water to neutral $\mathrm{pH}$. Then all materials were soaked with hydrochloric acid in concentration $1 \mathrm{~mol} /$ $\mathrm{dm}^{3}$ for $19 \mathrm{~h}$ and washed again with distilled water until the filtrate became neutral. 
Structure characterization of carbonaceous materials was carried out by $\mathrm{N}_{2}$ adsorption-desorption isotherms measured at $-196^{\circ} \mathrm{C}$ using Quantochrome Autosorb Instrument. Before analysis all samples were degassed at $200^{\circ} \mathrm{C}$ under vacuum for $16 \mathrm{~h}$. The specific surface area was estimated using the Brunauer-Emmett-Teller equation. Micropore volume was assessed by DFT model used to the nitrogen adsorption. The total pore volumes were calculated on the basis of the volume of $\mathrm{N}_{2}$ adsorbed at a relative pressure. $\mathrm{CO}_{2}$ adsorption capacity at $0^{\circ} \mathrm{C}$ and at $25^{\circ} \mathrm{C}$ was determined using Quantachrome Autosorb Instrument.

\section{RESULTS AND DISCUSSION}

The results of surface properties of all activated carbons are gathered in Table 1. It can be noticed that the highest specific surface area $\left(\mathrm{S}_{\mathrm{BET}}\right)$ values were found for samples carbonized at $900^{\circ} \mathrm{C}$. The values of $\mathrm{S}_{\mathrm{BET}}$ of HN900,WN900 and PN900 were $1963 \mathrm{~m}^{2} / \mathrm{g}, 1468 \mathrm{~m}^{2} / \mathrm{g}$ and $1962 \mathrm{~m}^{2} / \mathrm{g}$ respectively. Furthermore, $\mathrm{S}_{\mathrm{BET}}$ increased with the rise of carbonization temperature. Carbonization temperature also had an influence on micropore volume $\left(\mathrm{V}_{\text {mic }}\right)$ and total pore volume $\left(\mathrm{V}_{\text {tot }}\right)$ of examined samples. The highest values of $V_{\text {mic }}$ and $V_{\text {tot }}$ were obtained for samples carbonized at $900^{\circ} \mathrm{C}$. The values of $\mathrm{V}_{\text {mic }}$ and $\mathrm{V}_{\text {tot }}$ were in the range $0.22-0.68 \mathrm{~cm}^{3} / \mathrm{g}$ and $0.26-1.15$ $\mathrm{cm}^{3} / \mathrm{g}$ respectively.

Table 1. Activated carbons surface properties

\begin{tabular}{|l|c|c|c|}
\hline Sample & $\begin{array}{c}S_{\text {BET }} \\
{\left[\mathrm{m}^{2} / \mathrm{g}\right]}\end{array}$ & $\begin{array}{c}\mathrm{V}_{\text {mic }} \\
{\left[\mathrm{cm}^{3} / \mathrm{g}\right]}\end{array}$ & $\begin{array}{c}\mathrm{V}_{\text {tot }} \\
{\left[\mathrm{cm}^{3} / \mathrm{g}\right]}\end{array}$ \\
\hline HN600 & 591 & 0.22 & 0.26 \\
\hline HN700 & 870 & 0.31 & 0.39 \\
\hline HN800 & 1297 & 0.47 & 0.61 \\
\hline HN900 & 1963 & 0.64 & 1.15 \\
\hline WN600 & 663 & 0.24 & 0.30 \\
\hline WN700 & 927 & 0.34 & 0.39 \\
\hline WN800 & 1277 & 0.44 & 0.74 \\
\hline WN900 & 1468 & 0.52 & 0.76 \\
\hline PN600 & 629 & 0.24 & 0.28 \\
\hline PN700 & 979 & 0.35 & 0.41 \\
\hline PN800 & 1212 & 0.43 & 0.51 \\
\hline PN900 & 1962 & 0.68 & 1.03 \\
\hline
\end{tabular}

Figure 1. shows nitrogen adsorption-desorption isotherms of activated carbons made from hazelnut shells (Fig. 1a), walnut shells (Fig. 1b) and peanut shells (Fig. 1c). These isotherms are type I which means that at the lowest relative pressure the $\mathrm{N}_{2}$ uptake is the highest. When the relative pressure increases the uptake of gas starts to plateau. This result indicates that examined activated carbons had a well-developed microporous structure. No hysteresis loops or very small ones (mainly for samples carbonized at $900^{\circ} \mathrm{C}$ ) were found which suggests the lack of mesopores or their very low volume and implies the advantage of micropores.

Pore size distribution was calculated by applying DFT theory to $\mathrm{CO}_{2}$ adsorption data at $0^{\circ} \mathrm{C}$ and $\mathrm{N}_{2}$ adsorption data at $-196^{\circ} \mathrm{C}$. Figure 2 . shows the micropore size distribution curves of all examined samples (HN, WN and $\mathrm{PN})$. The pore diameter range $(0.3-0.8 \mathrm{~nm})$ indicates that studied activated carbons developed a microporous structure. In addition, the presence of very low volume mesopores was noticed (Fig. 3). The largest mesopore
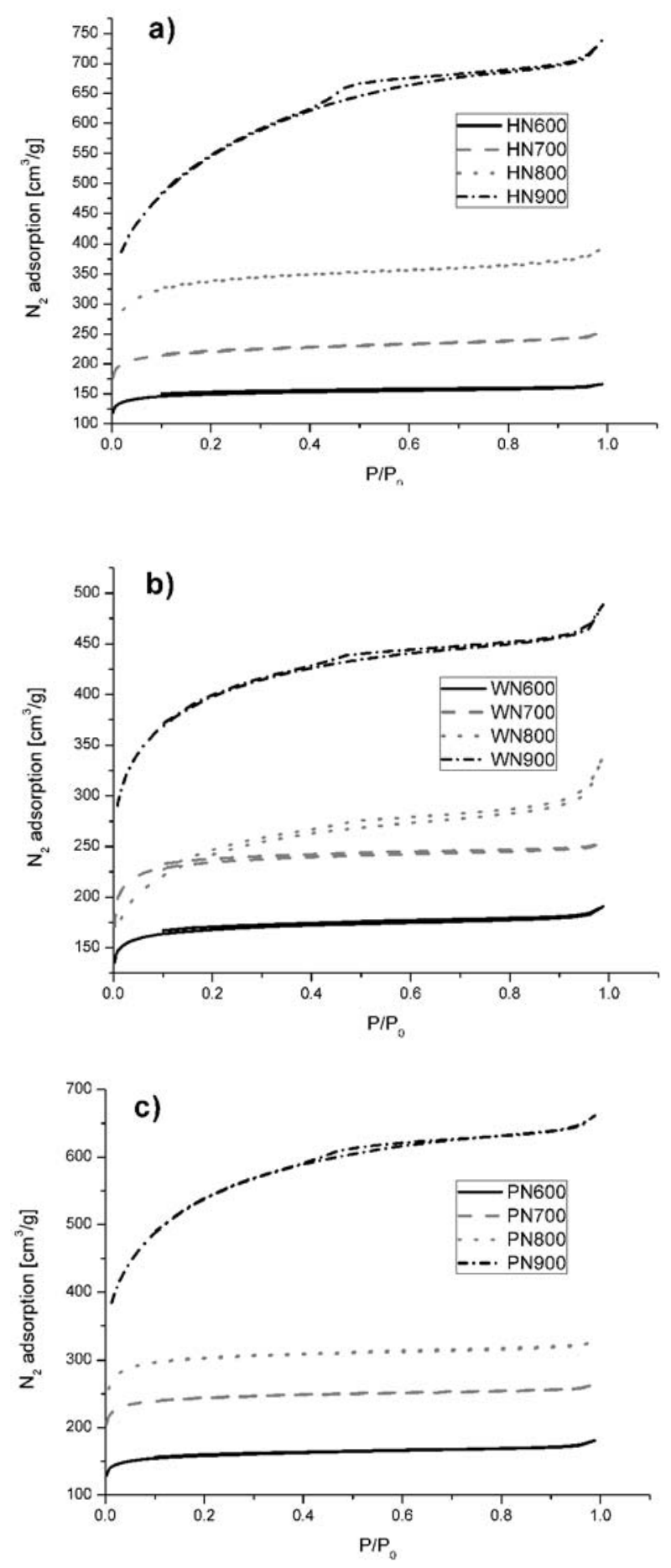

Figure 1. Adsorption and desorption isotherms of N2 for hazelnut shells (a), walnut shells (b) and peanut shells (c)

volume up to 6-8 $\mathrm{nm}$ was found for samples carbonized at $900^{\circ} \mathrm{C}$.

The size and volume of micropores have a crucial effect on $\mathrm{CO}_{2}$ adsorption capacity. The more microporous is the activated carbon the more effective is the gas adsorption. Adsorption temperatures have an influence on pore volume of activated carbons and their ability to capture $\mathrm{CO}_{2}$.

To quantify the accurate range of micropores for $\mathrm{CO}_{2}$ adsorption at $0^{\circ} \mathrm{C}$ and $25^{\circ} \mathrm{C}$, the correlation between the amounts of $\mathrm{CO}_{2}$ adsorbed on all activated carbons and their pore volume in the specific ranges was studied. The plots of $\mathrm{CO}_{2}$ adsorption capacity versus pore volume in 

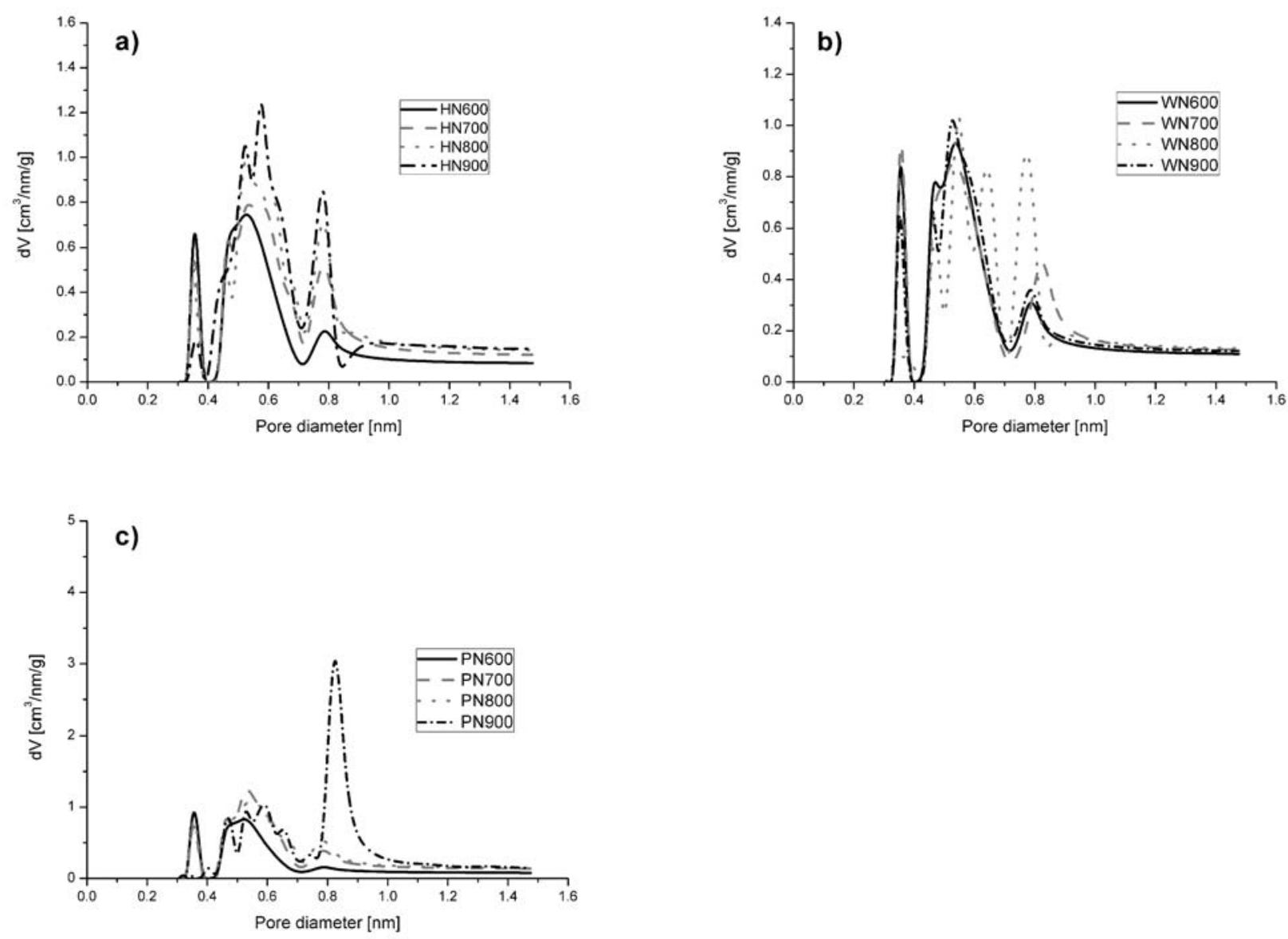

Figure 2. Micropore size distribution curves of activated carbons from hazelnut shells (a), walnut shells (b) and peanut shells (c)
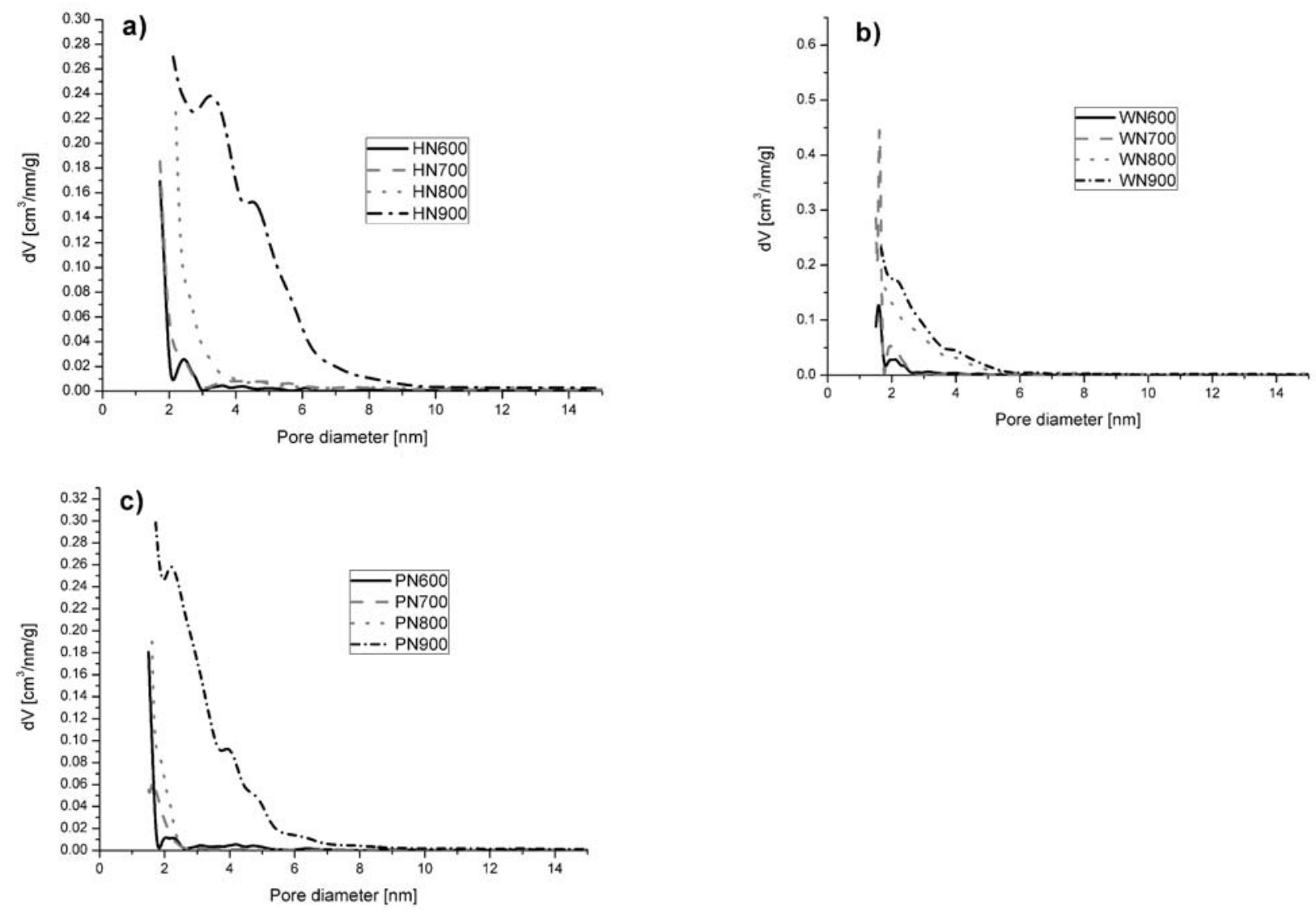

Figure 3. Micropore and mesopore size distribution curves of activated carbons from hazelnut shells (a), walnut shells (b) and peanut shells (c) 

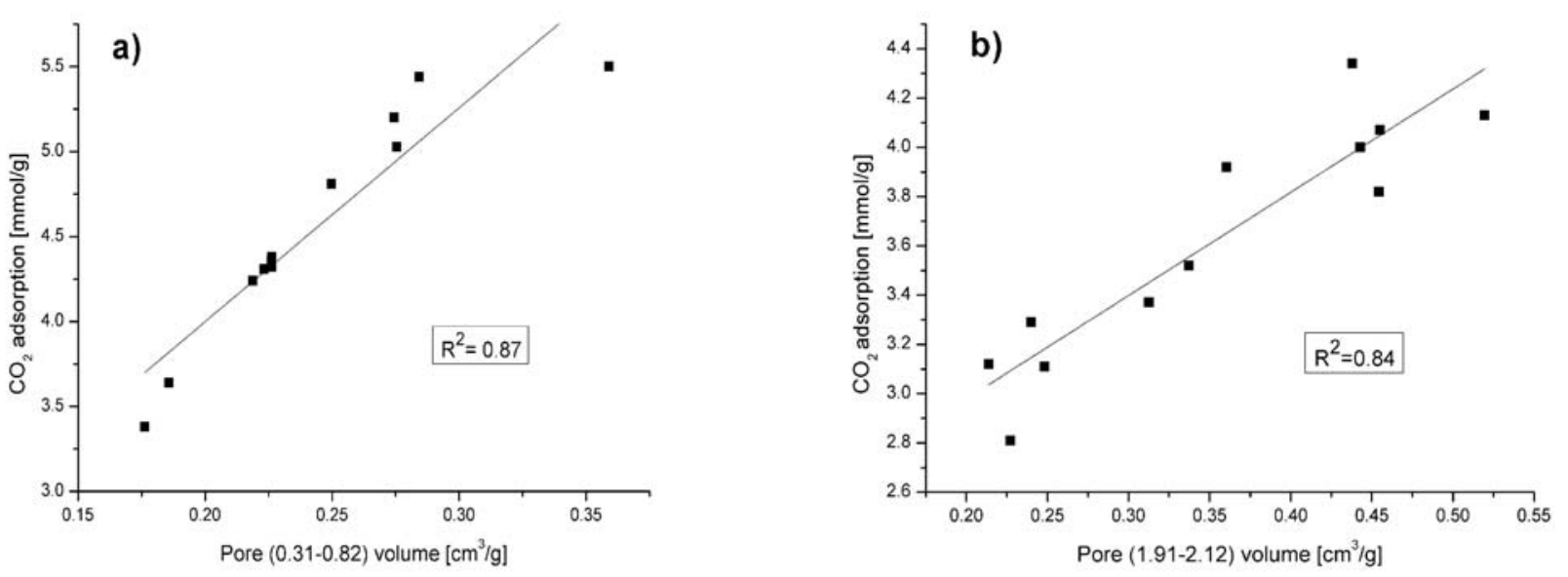

Figure 4. The best linear relationship between the volume of pores in correlation to $\mathrm{CO}_{2}$ adsorption at $0^{\circ} \mathrm{C}(\mathrm{a})$ and $25^{\circ} \mathrm{C}(\mathrm{b})$
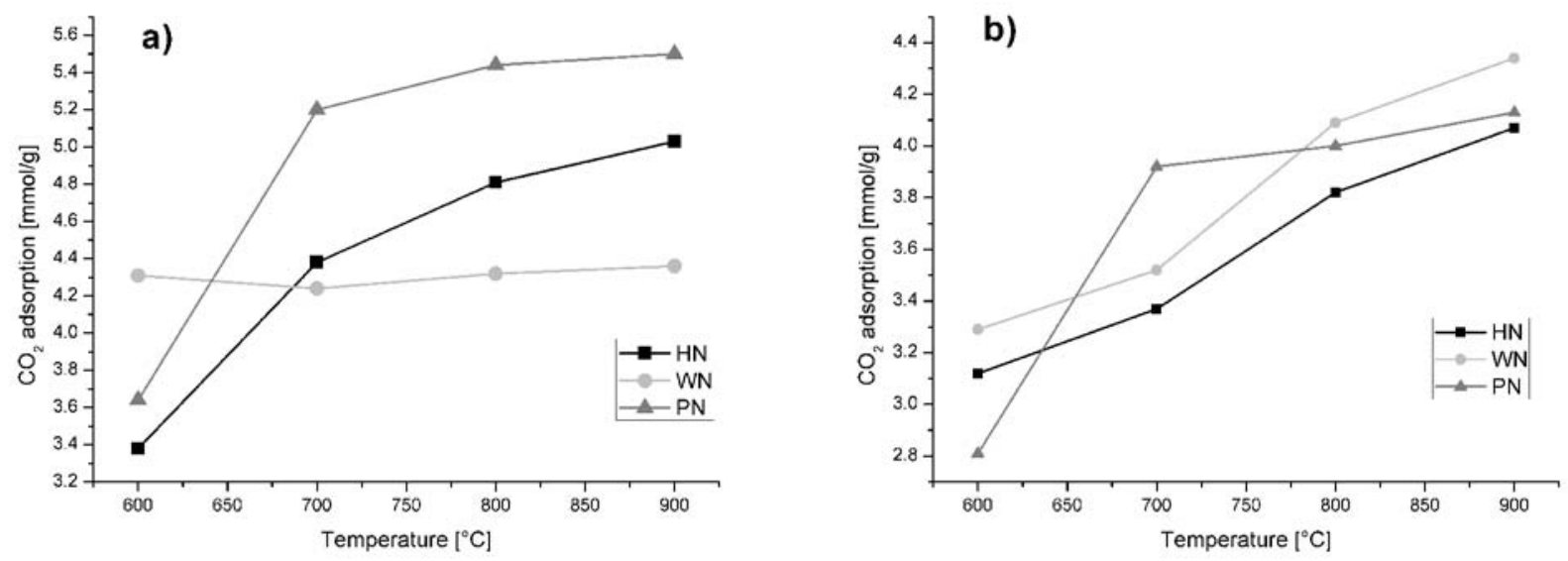

Figure 5. $\mathrm{CO}_{2}$ adsorption levels at $0^{\circ} \mathrm{C}(\mathrm{a})$ and $25^{\circ} \mathrm{C}(\mathrm{b})$ in correlation to carbonization temperature

obtained in this study. For activated carbon, carbonized at $700^{\circ} \mathrm{C}, \mathrm{CO}_{2}$ adsorption value was $1.54 \mathrm{mmol} / \mathrm{g}$ at $25^{\circ} \mathrm{C}$, whereas the value of $\mathrm{CO}_{2}$ adsorption on activated carbon produced in the same conditions in this research was 3.92 $\mathrm{mmol} / \mathrm{g}$. This result can be caused by differences in the preparation of activated carbons, such as carbonization of raw material before the activation process.

\section{CONCLUSIONS}

Activated carbons prepared from hazelnut shells, walnut shells and peanut shells can be used as an effective and cheap adsorbent of $\mathrm{CO}_{2}$ with high surface areas. With the increase of carbonization temperature specific surface area of studied samples increased. The highest $\mathrm{S}_{\mathrm{BET}}$ values and $\mathrm{CO}_{2}$ adsorption levels at $0^{\circ} \mathrm{C}$ and $25^{\circ} \mathrm{C}$ were found for samples carbonized at $900^{\circ} \mathrm{C}$. The nitrogen adsorption-desorption isotherms and the micropore size distribution curves show that activated carbons had a well-developed microporous structure. At $0^{\circ} \mathrm{C}$ the $\mathrm{CO}_{2}$ adsorption took place mostly in micropores in the range of $0.31-0.82 \mathrm{~nm}$ and at $25^{\circ} \mathrm{C}$ in the pores from $1.91 \mathrm{~nm}$ to $2.12 \mathrm{~nm}$. Preliminary carbonization of raw material before activation, especially of peanut shells, have a negative influence on adsorption properties of activated carbons.

\section{LITERATURE CITED}

1. Xiao-Gen, S. \& Hui-Qiang L. (2009). Discussion on lowcarbon economy and low-carbon building technology. Nat. Sci. 1, 37-40. DOI: 10.4236/ns.2009.11007.
2. Leung, D.Y.C., Caramanna, G. \& Maroto-Valer, M.M. (2014). An overview of current status of carbon dioxide capture and storage technologies. Renew. Sust. Energ. Rev. 39, 426-443. DOI: 10.1016/j.rser.2014.07.093.

3. Gong, J. Michalkiewicz, B., Chen, X., Mijowska, E., Liu, J., Jiang, Z., Wen, X. \& Tang, T. (2014). Sustainable Conversion of Mixed Plastics into Porous Carbon Nanosheets with High Performances in Uptake of Carbon Dioxide and Storage of Hydrogen. ACS Sustainable Chem. Eng. 2, 2837-2844. DOI: $10.1021 / \mathrm{sc} 500603 \mathrm{~h}$.

4. Wang, Y.X., Liu, B.S. \& Zheng, C. (2010). Preparation and Adsorption Properties of Corncob-Derived Activated Carbon with High Surface Area. J. Chem. Eng. 55, 4669-4676. DOI: $10.1021 / \mathrm{je} 1002913$.

5. Alves Fiuza, Jr., R., Medeiros de Jesus Neto R., Bacelar Correia, L. \& Carvalho Andrade, H.M. (2015). Preparation of granular activated carbons from yellow mombin fruit stones for $\mathrm{CO}_{2}$ adsorption. J. Environ. Manage. 161, 198-205. DOI: 10.1016/j.jenvman.2015.06.053.

6. Kapica-Kozar, J., Kusiak-Nejman, E., Wanag, A., Kowalczyk, Ł., Wrobel, R.J., Mozia, S. \& Morawski, A.W. (2015). Alkali-treated titanium dioxide as adsorbent for $\mathrm{CO}_{2}$ capture from air. Micropor. Mesopor. Mat. 202, 241-249. DOI: 10.1016/j. micromeso.2014.10.013.

7. Kapica-Kozar, J., Piróg, E., Kusiak-Nejman, E., Wrobel, R.J., Gęsikiewicz-Puchalska, A., Morawski, A.W., Narkiewicz, U. \& Michalkiewicz, B. (2017). Titanium dioxide modified with various amines used as sorbents of carbon dioxide. New J. Chem. DOI: 10.1039/c6nj02808j.

8. Michalkiewicz, B., Majewska, J., Kądziołka, G., Bubacz, K., Mozia, S. \& Morawski, A.W. (2014). Reduction of $\mathrm{CO}_{2}$ by adsorption and reaction on surface of $\mathrm{TiO}_{2}$-nitrogen modified photocatalyst, J. $\mathrm{CO}_{2}$ Util. 5, 47-52. DOI: $10.1016 / \mathrm{j}$. jcou.2013.12.004. 
9. Romero-Hermida, I., Santos, A., Pérez-López, R., GarcíaTenorio, R., Esquivias, L. \& Morales-Flórez, V. (2017). New method for carbon dioxide mineralization based on phosphogypsum and aluminium-rich industrial wastes resulting in valuable carbonated by-products. J. $\mathrm{CO}_{2}$ Util. 18, 15-22. DOI: 10.1016/j.jcou.2017.01.002.

10. Bradley, M.J., Ananth, R., Willauer, H.D., Baldwin, J.W., Hardy, D.R., DiMascio, F. \& Williams, F.W. (2017). The role of catalyst environment on $\mathrm{CO}_{2}$ hydrogenation in a fixed-bed reactor. J. $\mathrm{CO}_{2}$ Util. 17, 1-9. DOI: 10.1016/j.jcou.2016.10.014.

11. Michalkiewicz, B., Sreńscek-Nazzal, J. \& Ziebro, J. (2009). Optimization of Synthesis Gas Formation in Methane Reforming with Carbon Dioxide. Catal. Lett. 129, 142-148. DOI: 10.1007/s10562-008-9797-6.

12, Pakhare, D. \& Spivey, J. (2014). A review of dry $\left(\mathrm{CO}_{2}\right)$ reforming of methane over noble metal catalysts. Chem. Soc. Rev. 43, 7813-7837. DOI: 10.1039/C3CS60395D.

13, Michalkiewicz, B. (2004). Partial oxidation of methane to formaldehyde and methanol using molecular oxygen over Fe-ZSM-5. Appl. Catal. A-Gen. 277, 147-153. DOI: 10.1016/j. apcata.2004.09.005.

14. Markowska, A. \& Michalkiewicz, B. (2009). Biosynthesis of methanol from methane by Methylosinus trichosporium OB3b. Chem. Pap. 63, 105-110. DOI: 10.2478/s11696-008-0100-5.

15. Michalkiewicz, B. (2003). Methane conversion to methanol in condensed phase. Kinet. Catal. 44, 801-805. DOI: 10.1023/B:KICA.0000009057.79026.0b.

16. Michalkiewicz, B., Sreńscek-Nazzal, J., Tabero, P., Grzmil, B. \& Narkiewicz, U. (2008). Selective methane oxidation to formaldehyde using polymorphic T, $\mathrm{M}$ and $\mathrm{H}$ forms of niobium (V) oxide as catalysts. Chem. Pap. 62, 106-113. DOI: 10.2478/ s11696-007-0086-4.

17. Michalkiewicz, B. (2005). Kinetics of partial methane oxidation process over the Fe-ZSM-5 catalysts. Chem. Pap. 59, 403-408. DOI: 10.1016/j.apcata.2004.09.005.

18. Michalkiewicz, B., Jarosinska, M. \& Lukasiewicz, I. (2009). Kinetic study on catalytic methane esterification in oleum catalyzed by iodine. Chem. Eng. J. 154, 156-161. DOI: 10.1016/j.cej.2009.03.046.

19. Michalkiewicz, B. \& Balcer, S. (2012). Bromine catalyst for the methane to methyl bisulfate reaction. Pol. J. Chem. Technol. 14, 19-21. DOI: 10.2478/v10026-012-0096-z.

20. Michalkiewicz, B. (2011). Methane oxidation to methyl bisulfate in oleum at ambient pressure in the presence of iodine as a catalyst. Appl. Catal. A-Gen. 394, 266-268. DOI: 10.1016/j.apcata.2011.01.014.

21. Michalkiewicz, B., Kalucki, K. \& Sosnicki, J.G. (2003). Catalytic system containing metallic palladium in the process of methane partial oxidation. J. Catal. 215, 14-19. DOI: 10.1016/ S0021-9517(02)00088-X.

22. Michalkiewicz, B. (2006). The kinetics of homogeneous catalytic methane oxidation. Appl. Catal. A-Gen. 307, 270-274. DOI: 10.1016/j.apcata.2006.04.006.

23. Jarosińska, M., Lubkowski, K., Sośnicki, J.G. \& Michalkiewicz, B. (2008). Application of halogens as catalysts of $\mathrm{CH}_{4}$ esterification. Catal. Lett. 126, 407-412. DOI: 10.1007/ s10562-008-9645-8.

24. Majewska, J. \& Michalkiewicz, B. (2014). Carbon nanomaterials produced by the catalytic decomposition of methane over Ni/ZSM-5 Significance of Ni content and temperature. New Carbon Mater. 29, 102-108. DOI: 10.1016/ S1872-5805(14)60129-3.

25. Ziebro, J., Lukasiewicz, I., Borowiak-Palen, E. \& Michalkiewicz, B. (2010). Low temperature growth of carbon nanotubes from methane catalytic decomposition over nickel supported on a zeolite. Nanotechnology 21, 1-6. DOI: 10.1088/0957$4484 / 21 / 14 / 145308$.

26. Ziebro, J., Skorupinska, B., Kadziolka, G. \& Michalkiewicz, B. (2013). Synthesizing Multi-walled Carbon Nanotubes over a Supported-nickel Catalyst. Fuller. Nanotub. Car. N. 21, 333-345. DOI: 10.1080/1536383X.2011.613543.

27. Majewska, J. \& Michalkiewicz, B. (2016). Preparation of Carbon Nanomaterials over Ni/ZSM-5 Catalyst Using Simplex Method Algorithm. Acta Phys. Pol. A 129, 153-157. DOI: 10.12693/APhysPolA.129.153.

28. Ziebro, J., Lukasiewicz, I., Grzmil, B., Borowiak-Palen, E. \& Michalkiewicz, B. (2009). Synthesis of nickel nanocapsules and carbon nanotubes via methane CVD. J. Alloy. Compd. 485, 695-700. DOI: 10.1016/j.jallcom.2009.06.039.

29. Majewska, J. \& Michalkiewicz, B. (2013). Low temperature one-step synthesis of cobalt nanowires encapsulated in carbon. Appl. Phys. A-Mater. 111, 1013-1016. DOI: 10.1007/ s00339-013-7698-z.

30. Michalkiewicz, B. \& Majewska, J. (2014). Diameter-controlled carbon nanotubes and hydrogen production. Int. J. Hydrogen Energ. 39, 4691-4697. DOI: 10.1016/j.ijhydene.2013.10.149.

31. Grams, J., Potrzebowska, N., Goscianska, J., Michalkiewicz, B. \& Ruppert, A.M. (2016). Mesoporous silicas as supports for Ni catalyst used in cellulose conversion to hydrogen rich gas, Int. J. Hydrogen Energ. 41, 8656-8667. DOI: 10.1016/j. ijhydene.2015.12.146.

32. Michalkiewicz, B. \& Koren, Z.C. (2015). Zeolite membranes for hydrogen production from natural gas: state of the art. J. Porous Mat. 22, 635-46. DOI: 10.1007/s10934-015-9936-6.

33. Kapica-Kozar, J., Piróg, E., Wróbel, R.J., Mozia, S., Kusiak-Nejman, E., Morawski, A.W., Narkiewicz, U. \& Michalkiewicz, B. (2016). $\mathrm{TiO}_{2} /$ titanate composite nanorod obtained from various alkali solutions as $\mathrm{CO}_{2}$ sorbents from exhaust gases. Micropor. Mesopor. Mat. 231, 117-127. DOI: 10.1016/j. micromeso.2016.05.024.

34. Wenelska, K., Michalkiewicz, B., Gong, J., Tang, T., Kaleńczuk, R., Chen, X. \& Mijowska, E. (2013). In situ deposition of Pd nanoparticles with controllable diameters in hollow carbon spheres for hydrogen storage. Int. J. Hydrogen Energ. 38, 16179-16184. DOI: 10.1016/j.ijhydene.2013.10.008.

35. Wenelska, K., Michalkiewicz, B., Chen, X. \& Mijowska, E. (2014). Pd nanoparticles with tunable diameter deposited on carbon nanotubes with enhanced hydrogen storage capacity Energy 75, 549-554. DOI: 10.1016/j.energy.2014.08.016.

36. Sreńscek-Nazzal, J., Kamińska, W., Michalkiewicz, B. \& Koren, Z.C. (2013). Production, characterization and methane storage potential of $\mathrm{KOH}$-activated carbon from sugarcane molasses. Ind. Crop. Prod. 47, 153-159. DOI: 10.1016/j.indcrop.2013.03.004.

37. Alcañiz-Monge, J., Lozano-Castelló, D., Cazorla-Amorós, D. \& Linares-Solano, A. (2009). Fundamentals of methane adsorption in microporous carbons. Micropor. Mesopor. Mat. 124, 110-116. DOI: 10.1016/j.micromeso.2009.04.041.

38. Sun, Y., Liu, C., Su, W., Zhou, Y. \& Zhou, L. (2009). Principles of methane adsorption and natural gas storage. Adsorption 15, 133-137. DOI: 10.1007/s10450-009-9157-x.

39. Sreńscek-Nazzal, J., Narkiewicz, U., Morawski, A., Wróbel, R., Gęsikiewicz-Puchalska, A. \& Michalkiewicz, B. (2016). Modification of commercial activated carbons for $\mathrm{CO}_{2}$ adsorption. Acta Phys. Pol. A 129(3), 394-401. DOI: 10.12693/ APhysPolA.129.394.

40. Deng, S., Wei, H., Chen, T., Wang, B., Huang, J. \& Yu, G. (2014). Superior $\mathrm{CO}_{2}$ adsorption on pine nut shell-derived activated carbons and the effective micropores at different temperatures. Chem. Eng. J. 253, 46-54. DOI: 10.1016/j. cej.2014.04.115.

41. Kwiatkowski, M., Sreńscek-Nazzal, J. \& Michalkiewicz, B. (2017) An analysis of the effect of the additional activation process on the formation of the porous structure and pore size distribution of the commercial activated carbon WG-12, Adsorption, accepted DOI: 10.1007/s10450-017-9867-4.

42. Sreńscek-Nazzal, J., Narkiewicz, U., Morawski, A.W., Wróbel, R.J. \& Michalkiewicz, B. (2015). Comparison of Optimized Isotherm Models and Error Functions for Carbon 
Dioxide Adsorption on Activated Carbon. J. Chem. Eng. Data 60, 3148-3158. DOI: 10.1021/acs.jced.5b00294.

43. Gesikiewicz-Puchalska, A., Zgrzebnicki, M. \& Michalkiewicz, B. (2017). Improvement of $\mathrm{CO}_{2}$ uptake of activated carbons by treatment with mineral acids. Chem. Eng. J. 309, 159-171. DOI: 10.1016/j.cej.2016.10.005.

44. Sreńscek-Nazzal, J. \& Michalkiewicz, B. (2011). The simplex optimization for high porous carbons preparation. Pol. J. Chem. Tech. 13(4), 63-70. DOI: 10.2478/v10026-011-0051-4. 45, Savova, D., Apak, E., Ekinci, E., Yardim, F., Petrov N., Budinova, T., Razvigorova, M. \& Minkova, V. (2001). Biomass conversion to carbon adsorbents and gas. Biomass Bioenerg. 21, 133-142. DOI: 10.1016/S0961-9534(01)00027-7.

46. Sun, Y. \& Webley, P.A. (2011). Preparation of Activated Carbons with Large Specific Surface Areas from Biomass Corn$\mathrm{cob}$ and Their Adsorption Equilibrium for Methane,Carbon Dioxide, Nitrogen, and Hydrogen. Ind. Eng. Chem. Res. 50, 9286-9294. DOI: 10.1021/ie1024003.

47. Kapica, J., Pełech, R., Przepiórski, J. \& Morawski, A.W. (2002). Kinetics of the Adsorption of copper and lead ions from aqueous solution on to WD-ekstra activated carbon. Adsorpt. Sci. Technol. 20, 441-452. DOI: 10.1260/026361702320644734.

48. Przepiórski, J., Czyżewski, A., Kapica, J., Moszyński, D., Grzmil, B., Tryba, B., Mozia, S. \& Morawski, A.W. (2012). Low temperature removal of $\mathrm{SO}_{2}$ traces from air by $\mathrm{MgO}$-loaded porous carbons. Chem. Eng. J. 191, 147-153. DOI: 10.1016/j.cej.2012.02.087.

49. Czyżewski, A., Kapica, J., Moszyński, D., Pietrzak, R., Przepiórski, J. (2013). On competitive uptake of $\mathrm{SO}_{2}$ and $\mathrm{CO}_{2}$ from air by porous carbon containing $\mathrm{CaO}$ and $\mathrm{MgO}$. Chem. Eng. J. 226, 348-356. DOI: 10.1016/j.cej.2013.04.061

50. Wróblewska, A. \& Makuch, E. (2014). Regeneration of the Ti-SBA-15 Catalyst Used in the Process of Allyl Alcohol Epoxidation with Hydrogen Peroxide. J. Adv. Oxid. Technol. 17(1), 44-52. DOI: 10.1515/jaots-2014-0106.

51. Wróblewska, A. (2014). The Epoxidation of Limonene over the TS-1 and Ti-SBA-15 Catalysts. Molecules 19, 19907-19922. DOI: 10.3390/molecules191219907.

52. Wróblewska, A., Ławro, E. \& Milchert, E. (2006). Technological Parameter Optimization for Epoxidation of Methallyl Alcohol by Hydrogen Peroxide over TS-1 Catalyst. Ind. Eng. Chem. Res. 45, 7365-7373. DOI: 10.1021/ie0514556.

53. Wróblewska, A. (2006). Optimization of the reaction parameters of epoxidation of allyl alcohol with hydrogen peroxide over TS-2 catalyst. Appl. Catal. A- Gen. 309, 192-200. DOI: 10.1016/j.apcata.2006.05.004.

54. Chen, Y., Zhu, Y., Wang, Z., Li, Y., Wang, L., Ding, L., Gao, X., Ma, Y. \& Guo, Y. (2011). Application studies of activated carbon derived from rice husks produced by chemical-thermal process-A review. Adv. Coll. Int. Sci. 163, 39-52. DOI: 10.1016/j.cis.2011.01.006.

55. Młodzik, J., Wróblewska, A., Makuch, E., Wróbel, R.J. \& Michalkiewicz, B. (2016). Fe/EuroPh catalysts for limonene oxidation to 1,2-epoxylimonene, its diol, carveol, carvone and perillyl alcohol. Catal. Today 268, 111-120. DOI: 10.1016/j. cattod.2015.11.010.

56. Wróblewska, A., Makuch, E., Młodzik, J., Koren, Z. \& Michalkiewicz, B. (2016). Fe/Nanoporous Carbon Catalysts Obtained from Molasses for the Limonene Oxidation Process. Catal. Lett. DOI: 10.1007/s10562-016-1910-7.

57. Wróblewska, A., Makuch, E., Młodzik, J. \& Michalkiewicz, B. (2016). Fe-carbon nanoreactors obtained from molasses as efficient catalysts for limonene oxidation. Green Process. Synth. DOI: 10.1515/gps-2016-0148

58. Adib Yahya, M., Al-Qodah, Z. \& Zanariah Ngah, C.W. (2015). Agricultural bio-waste materials as potential sustainable precursors used for activated carbon production: A review. Renew. Sust. Energ. Rev. 46, 218-235. DOI: 10.1016/j. rser.2015.02.051.

59. Rashidi, N.A., Yusup, S. \& Borhan, A. (2014). Development of Novel Low-Cost Activated Carbon for Carbon Dioxide
Capture. Int. J. Chem. Eng. Appl. 5(29), 90-94. DOI: 10.7763/ IJCEA.2014.V5.357.

60. Aygun, A., Yenisoy-Karakas, S. \& Duman, I. (2003). Production of granular activated carbon from fruit stones and nutshells and evaluation of their physical, chemical and adsorption properties. Micropor. Mesopor. Mat. 66, 189-195. DOI: $10.1016 /$ j.micromeso.2003.08.028.

61. Glonek, K., Sreńscek-Nazzal, J., Narkiewicz, U., Morawski, A., Wróbel, R. \& Michalkiewicz, B. (2016). Preparation of Activated Carbon from Beet Molasses and $\mathrm{TiO}_{2}$ as the Adsorption of $\mathrm{CO}_{2}$. Acta. Phys. Pol. A 129(1), 158-161. DOI: 10.12693/APhysPolA.129.158.

62. Młodzik, J., Sreńscek-Nazzal, J., Narkiewicz, U., Morawski, A., Wróbel, R. \& Michalkiewicz, B. (2016). Activated carbons from molasses as $\mathrm{CO}_{2}$ sorbents. Acta. Phys. Pol. A 129(3), 402-404. DOI: 10.1269/APhysPolA.129.402.

63. Serafin, J., Narkiewicz, U., Morawski, A.W., Wróbel, R.J. \& Michalkiewicz, B. Highly microporous activated carbons from biomass for $\mathrm{CO}_{2}$ capture and effective micropores at different conditions. J. $\mathrm{CO}_{2}$ Utilization.

64. Deng, S., Hu, B., Chen, T., Wang, B., Huang, J., Wang, Y. \& Yu, G. (2015). Activated carbons prepared from peanut shell and sunflower seed shell for high $\mathrm{CO}_{2}$ adsorption. Adsorption 21, 125-133. DOI 10.1007/s10450-015-9655-y.

65. Kwiatkowski, M., Fierro, V. \& Celzard, A. (2017). Numerical studies of the effects of process conditions on the development of the porous structure of adsorbents prepared by chemical activation of lignin with alkali hydroxides. J. Coll. Int. Sci. 486, 277-286. DOI: 10.1016/j.jcis.2016.10.003.

66. Kwiatkowski, M. \& Broniek, E. (2013). Application of the LBET class adsorption models to the analysis of microporous structure of the active carbons produced from biomass by chemical activation with the use of potassium carbonate. $J$. Coll. Int. Sci. 427, 47-52. DOI: 10.1016/j.colsurfa.2013.03.002.

67. Kwiatkowski, M. \& Broniek, E. (2012). Application of the LBET class adsorption models to analyze influence of production process conditions on the obtained microporous structure of activated carbons. Coll. Surf. A. 411, 105-110. DOI: 10.1016/j.colsurfa.2012.06.046.

68. Rechnia, P., Malaika, A., Najder-Kozdrowska, L. \& Kozłowski, M. (2012). The effect of ethanol on carbon-catalysed decomposition of methane. Int. J. Hydrogen Energy 37, 7512-7520. DOI: 10.1016/j.ijhydene.2012.02.014.

69. Sayan, E. (2006). Ultrasound-assisted preparation of activated carbon from alkaline impregnated hazelnut shell: An optimization study on removal of from aqueous solution. Chem. Eng. J. 115, 213-218. DOI: 10.1016/j.cej.2005.09.024.

70. Unur, E. (2013). Functional nanoporous carbons from hydrothermally treated biomass for environmental purification. Micropor. Mesopor. Mat. 168, 92-101. DOI: 10.1016/j. micromeso.2012.09.027.

71. Gonzalez, J.F., Roman S., Gonzalez-Garcia, C.M., Valente Nabais, J.M. \& Ortiz, A.L. (2009). Porosity development in activated carbons prepared from walnut shells by carbon dioxide or steam activation. Ind. Eng. Chem. Res. 48, 7474-7481. DOI: $10.1021 /$ ie $801848 x$.

72. Li, D., Tian, Y., Li, L., Li, J. \& Zhang, H. (2015). Production of highly microporous carbons with large $\mathrm{CO}_{2}$ uptakes at atmospheric pressure by $\mathrm{KOH}$ activation of peanut shell char. $J$. Porous. Mater. 22, 1581-1588. DOI: 10.1007/s10934-015-0041-7.

73. David, E. \& Kopac, J. (2014). Activated carbons derived from residual biomass pyrolysis and their $\mathrm{CO}_{2}$ adsorption capacity. J. Anal. Appl. Pyrol. 110, 322-332. DOI: 10.1016/j. jaap.2014.09.021.

74. Rashidi, A.M., Kazemi, D., Izadi, N., Pourkhalil, M., Jorsaraei, A., Ganji, E. \& Lotfi, R. (2016). Preparation of nanoporous activated carbon and its application as nano adsorbent for $\mathrm{CO}_{2}$ storage. Korean J. Chem. Eng. 33(2), 616-622. DOI: $10.1007 / \mathrm{s} 11814-015-0149-0$. 